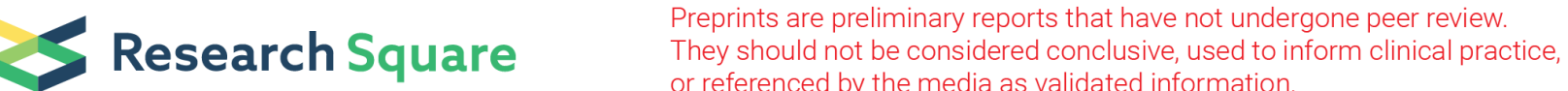

\section{Socio-demographic influences on the prevalence of enteric helminth and protozoan infections in newly arrived migrant workers in Qatar}

\section{Nadin Younes}

Qatar University

Jerzy M. Behnke

University of Nottingham

Ahmed Ismail

Ministry of public health

Marawan Abumadi ( $\sim$ Abumadi@qu.edu.qa )

Qatar university

Research article

Keywords:

Posted Date: March 19th, 2020

DOI: https://doi.org/10.21203/rs.3.rs-18027/v1

License: (c) (i) This work is licensed under a Creative Commons Attribution 4.0 International License. Read Full License 


\section{Abstract}

Background Intestinal parasitosis is a major concern for public health, especially in children from middle and low-income populations of tropical and subtropical areas. In this study, we explored the environmental and socio-demographic characteristics of immigrants in Doha Qatar, that might explain the persistence of the parasites that they harbor.

Methodology This cross-sectional survey was conducted among 2,486 newly arrived expatriates and those who visited Qatar previously during the period 2012-2014. Through questionnaires and census data, we characterised the socio-demographics conditions at an individual, family and neighborhood levels.

Results Combined protozoan infections were significantly associated with immigrants arriving in Doha for the first time. In univariate loglinear statistical models fitted in phase 1 of the analysis significant associations were observed between the prevalence of combined protozoan infections and personal and familial factors that included religion, the level of education of subjects, both parents' educational levels and their jobs, and number of siblings. Furthermore, environmental effects on the prevalence of protozoan infections included the country of origin; the floor of the house, toilet type, household content index, provision of household water, arable farming background showed a strong association with protozoan infections as well. However in phase 2, multifactorial binary logistic generalized linear models focusing only on the significant effects identified in phase 1 , showed that only five factors retained significance (age class, floor of house, household contents index, father's education, and number of siblings). The only factors that had a significant effect on the prevalence of helminth infections were the subjects age class and the mother's educational level.

Conclusion The prevalence of intestinal protozoan parasites among immigrants to Qatar is clearly multifactorial in origin, determined by key familial relationships of subjects and also the environment in which the subjects lived prior to their arrival in Qatar. Moreover our results suggest that screening protocols for applicants for visas/work permits need to be revised giving more careful attention to the intestinal protozoan infections that potential immigrants may harbor.

\section{Introduction}

Enteric infectious diseases continue to be a major public health problem especially in low- and middleincome populations $(1,2)$. Intestinal parasitic infections are one of the major causes of morbidity and mortality particularly in developing countries (3) and prevalence is known to be closely related to the educational levels of subjects, environmental factors, sanitary conditions, socio-economic status, inadequate medical care and lack of access to safe drinking water supplies (4-6). Studies have also shown that social and economic contexts are important determinants of human health, including diseases caused by parasitic organisms (2). 
Asymptomatic infected food handlers and housemaids are a potential source of infection for many intestinal parasites and other enteropathogenic infectious agents $(7,8)$. Economic migrants from these groups, but including also those engaged in other jobs such as laborers and drivers, who harbor parasitic infections carry them to the countries in which they settle unless they are treated before arrival (9). The transmission of parasites occurs directly or indirectly through food, water or hands, reinforcing the importance of fecal-oral and human-to-human transmission modes (10). Thus, food handlers with poor personal hygiene and inadequate knowledge of food safety could be the source of foodborne pathogens and may be implicated in the transmission of many infections to the local community, posing a particular infection risk to the public $(8,11,12)$.

Recently, the Arabian Gulf region has seen enormous progress in the living standards of its inhabitants and this has attracted immigrants seeking work from around the globe. In Qatar, most of the expatriates who work as drivers, food handlers, housemaids, and child/early care assistants come from a background of modest socio-economic living standard in their countries of origin. Many are from areas where enteric parasites are endemic, and where there is no or inadequate access to medical care services. It is important therefore to alert both the expatriates and the local communities in which they have settled about the risks of these contagious diseases, particularly the factors that facilitate parasitic transmission, to limit the spread of the infectious agents.

In an earlier paper on this dataset, we focused on the extrinsic (nationality and region of origin) and intrinsic factors (sex and age) that affected both combined helminth infections (all species combined and treated as one taxon) and protozoan infections among recently arrived immigrants to Qatar (13). Age, sex and nationality were all recorded at the Medical Commission as part of the routine clinical inspection of applicants for work permits. In the previous study, we found that only an age effect was significant for combined helminth infections. There was no difference in the prevalence of combined helminths between subjects from different regions of origin and no difference in the prevalence between the sexes. For combined protozoan infections both the regional effect and age effect were significant but, as with helminths, there was no difference in prevalence between the sexes.

In this study, we build on the earlier published analysis, seeking socio-demographic factors that might provide further explanations for the variation in prevalence of protozoan and helminth infections among immigrant workers. The factors used in this analysis were derived from a detailed survey instrument, in which, all the subjects were randomly chosen with the help of a trained translator, at initial presentation.

\section{Materials And Methods}

\section{Study population and Sample Collection}

We conducted a retrospective cross-sectional study on the prevalence of intestinal protozoa in Qatar among the expatriates in certain jobs (food handlers, housemaids, white collar, blue collar, and pink collar workers). Briefly, 2,486 subjects from 24 countries were screened during the period 2012-2014. Random stool samples were collected during routine health examinations of individuals who, soon after arrival in 
the country, reported to the Medical Commission in order to obtain work permit and were allocated to four age classes (age class 1 [ $16-22$ years, $n=303$ ]; Age class 2 [23-29 years, $n=856$ ]; Age class 3 [30-37 years, $n=823$ ] and age class 4 [38-58 years, $n=504]$ ), and to four regions of origin (Eastern Asia $(n=936)$, Western Asia $(n=1,289)$, Northern and Saharan Africa $(n=138)$ and sub-Saharan Africa $(n=123)$, as described by Abu Madi et al (14). The methods used for coproscopy have been fully described in Abu Madi et al (15).

\section{Ethics statement}

Ethical approval to undertake the study in the current design was obtained from the Medical Research Centre and Research Committee at HMC, Qatar (Research protocol \# 16367/16 (NPRP8-1556-3-313). Additionally,written informed consent was obtained from each participant on a document, that included an explanation of the significance of the study, participant requirements and rights, and information on sample collection. Confidentiality was maintained throughout and the identity of subjects was not available to us, other than through each individual's reference number. Age, sex, and geographical region were recorded for each patient before taking the specimen.

\section{Stool Examination}

Stool examination was carried out in a safety cabinet, where stool specimens were preserved in an ecofix preservative vial (Meridin Biosciences, Inc., Cincinnati, $\mathrm{OH}$ ). The contents were stirred with fine clean disposable wooden sticks to remove large clumps and mixed vigorously by vortex to homogenize the sample. To ensure adequate fixation of the homogenized stool, the sample was kept for half an hour at room temperature. The preserved specimen was mixed by vortex and filtered through a macro-con filtration unit for the removal of bulky debris. After filtration, $10 \%$ formalin and ethyl acetate were added, the sample was centrifuged for $10 \mathrm{~min}$ at 3,000 rpm, and the fluid containing diethyl ether and formalin was discarded. The pellet was resuspended by agitation, poured onto a microscope slide containing one drop of iodine, and examined microscopically for the presence/absence of parasite eggs/cysts and to enable identification of parasites in positive samples.

\section{Socio-demographic data collection and analysis}

A socio-demographic questionnaire was also completed for all participants by trained interviewers. Information obtained at interviews was first recorded on hard copies of printed pro-formas of the questionnaire. Subsequently, data were entered into an Excel workbook and subjected to quality control procedures. Numerical data were then imported into SPSS version 23 for analysis and were treated initially under two headings: personal and familial characteristics, and environmental factors reflecting aspects of living conditions in the respondents' home villages, towns or cities. Each recorded factor was divided into a range of levels which are given in Tables 2 and 3. Some were simple binary entries (e.g. yes or no, and coded as 1 and 0 respectively), others comprised more levels and were given numerical nominal coding, and finally, it was possible in some cases to scale the values provided by respondents (e.g. no of siblings). 
Personal and familial factors included; immigration status,religion, education, job/profession, monthly income, number of siblings, father's education, father's occupation/profession, mother's education, mother's occupation/profession.

Environmental factors including the ownership of house, number of people sharing a house, number of rooms, house construction, floor of house, toilet, provision of household water, whether the subject was a farmer, and whether the subject owned any domestic animals and if so how many different species. The number of animal species was based on a choice from dog, goat, cow, cat, chicken and other (examples specified by 27 subjects included birds, ducks, buffalo, ox, sheep, pig) and 1 point was given for each species. The household contents index was based on 1 point for each of the following: gas or electricity cooker, microwave oven, fridge, television, radio, computer, internet access, shower, bath, and car.

\section{Statistical Analysis}

Analysis of data was undertaken in two phases because of the number of potential explanatory factors recorded in the questionnaire. First, univariate log-linear models were fitted with each factor in turn and infection (either combined helminths or combined protozoan infections, each at 2 levels, present or absent), as described elsewhere (16). Then, the significant factors from the initial phase were selected, and multifactorial generalized linear models (GLMs) were fitted with a binary log link in SPSS 23, incorporating all the main effects and all relevant 2-way interactions. Because of the number of factors involved, this second phase was conducted in three separate stages. First model 1 was fitted with the significant familial factors from phase 1 , and then a second model (model 2) was fitted with the environmental factors, and in each case also including age class and region of origin of subjects as these had been shown earlier to have had a significant effect on INFECTION (14). In a third stage the significant factors from models 1 and 2 were included in model 3 that also incorporated age class and region of origin. Model simplification was by the backward selection, deleting the least significant interaction in turn at each successive cycle, until only significant 2-way interactions, and relevant main effects remained. Significance was based on the Wald $\chi^{2}$ output of the minimum sufficient model thus generated. The final minimum sufficient model was also tested by multifactorial loglinear analysis, to confirm parameter estimates.

Data are reported as prevalence values (percentage of infected subjects in relevant factor levels) with $95 \%$ confidence limits in parenthesis. We provide also odds ratios $+95 \%$ confidence limits for levels within each factor, using one level as the reference point in each case. Relationships between the prevalence of infection and levels within specific factors that showed a directional trend (meaningful increase across levels e.g. no of siblings in the family) were examined by the non-parametric Spearman's test in SPSS 23, and $R s$ is given. $\mathrm{P}$ values less than 0.05 were considered to indicate statistical significance.

\section{Results}


Two thousand, four hundred eighty-six samples (Male $=1351,54.3 \%$ and Female $=1135,45.7 \%$ ) were include in the study. The overall prevalence of infections with combined helminths was 7.0\% [6.03-8.05\%] and with combined protozoan infections $11.7 \%$ [10.40-12.93\%]. Table 1 shows the prevalence of each of the individual species that were detected. The prevalence of combined helminths and combined protozoa at each level of the personal, familial and environmental variables that were recorded are given in Tables $2 \& 3$.

\section{Personal and familial characteristics}

Interestingly, based on univariate analysis, no significant difference in prevalence of combined helminths between the newly and previously arrived immigrants was observed (table2). In contrast first time arrivals in Qatar had a significantly higher prevalence of combined protozoan infections. No significant difference in the prevalence of combined helminth infections was found between different religions, education status, job profession, income status, number of siblings, father's education, father's occupation and mother's occupation. The only factor that was found to have a significant effect on prevalence was the mother's educational level. However, there appeared no clear trend. Thus, while prevalence was lower among those whose mothers had experienced intermediate and high schools, prevalence was relatively high and similar among subjects whose mothers had only experienced elementary school and to those who went on to universities (Table 2).

The prevalence of combined protozoa was affected by immigration status (highest among first arrivals), religion (highest among Hindu, lowest among Buddhists), personal education (highest among those with none, lowest among graduates), number of siblings, father's educational level (highest if none, lowest if attended at least high school), father's job/profession (highest if none, lowest if a white collar worker) and mother's education (highest if none, lowest if she attended at least high school). Mother's job had borderline significance (highest in those with no job).

Even though the relationship between the presence/absence of helminths and the number of siblings in the family was not significant (Table 2), there was a significant positive correlation between prevalence and the number of siblings, as illustrated in Fig. $1\left(R_{s}=0.76, n=8, P=0.028\right)$. Moreover, in comparison to the families with no children, the odds ratios for all those with children were significantly higher. The prevalence of combined protozoa varied significantly among the different levels corresponding to the number of siblings, but there was no directional trend (highest among those with 6 , but surprisingly lowest among those with 5), not surprisingly the correlation between prevalence and no of siblings was not significant $\left(R_{s}=0.13, n=8, P=0.76\right)$.

\section{Environmental characteristics in country of origin}

The only environmental factor that showed a significant impact on the prevalence of combined helminths, the univariate analysis, was the household contents index, but no clear trend was found in relation to an increasing index, which is likely to reflect increasing affluence. Of note, several environmental factors were significantly associated with prevalence of combined protozoan; number of 
rooms in house (highest if 4, lowest if 5-25), floor of house (highest if soil, lowest if wooden floor or hard natural surface), type of toilet facility (highest in those living in houses with pit latrines), household contents index (surprisingly highest value among those with an index of 10 , but excepting this level, highest values were the bottom end of the index), household water supply (highest for those using river water, but also surprisingly high for those with internal water supplies, although low if using bottled water and also a covered well). There were no infections among those using shared taps, but the sample size for this group was small. Prevalence of combined protozoan infections was perhaps surprisingly higher among non-farmers compared with farmers.

\section{Controlling for combinations of socio-demographic and environmental factors in analysis of combined helminth infections}

The significant factors identified in the first phase as affecting the prevalence of combined helminth infections were age class of subjects, the number of siblings, mother's education and household contents index. Age class of subjects was reported as a significant factor in this data-set in our earlier publication (14). Following backward selection and model simplification, the minimum sufficient GLM model comprised only the main effects of age class (Wald $\chi^{2}{ }_{3}=12.2, P=0.007$ ) and a weak effect of the mother's education level (Wald $\chi^{2}{ }_{3}=9.7, P=0.046$ ) as factors influencing the prevalence of helminths in this data-set. However loglinear analysis identified also a weak significant interaction between age class, and the mothers education level $\left(\chi^{2}{ }_{12}=23.6, P=0.023\right)$ and this is presented in Table 4 . The highest prevalence of combined protozoan infections in age classes 1, 3 and 4 were among participants whose mothers had undergone tertiary level education, whereas among participants in age class 2 , the highest prevalence was among those whose mothers had no education.

\section{Controlling for combinations of socio-demographic and environmental factors in analysis of combined protozoan infections.}

We fitted a GLM that comprised all the significant personal and familial factors identified in table 1 ( 9 factors, comprising immigration, religion, education, father's education, father's occupation, number of siblings and mother's education, plus region of origin and age class) as main effects and their 2-way interactions. The minimum sufficient model (model 1 ) was age (Wald $\chi^{2}{ }_{3}=13.0, P=0.005$ ) as expected from Abu-Madi et (14), and then the number of siblings (Wald $\chi^{2}{ }_{7}=15.6, P=0.03$ ) and father's education (Wald $\chi^{2}{ }_{4}=32.5, P<0.001$ ). For model 2 we fitted all significant environmental factors in table 2 ( 8 factors comprising number of rooms in household, floor of house, toilet, household contents index, provision of household water, farmer plus age class and region of origin) as main effects and their 2-way interactions. Only household floor (Wald $\chi^{2}{ }_{8}=22.5, P=0.004$ ) and household contents index (Wald $\chi^{2}{ }_{10}=33.3, P<0.001$ ) retained significance. Region of origin of subjects was retained in the final model because Abu-Madi et al (16) had shown this to be a significant effect on the prevalence of combined protozoan infections (Wald $\left.\chi^{2}{ }_{3}=8.35, P=0.039\right)$, and as expected age class was also a significant factors $\left(\chi^{2}{ }_{3}=9.12, P=0.028\right)$. Finally, in model 3 we fitted all these significant factors and their 2-way interactions. Only five retained 
significance (age class, $\chi^{2}{ }_{3}=17.22, P=0.001$; floor of house, $\chi^{2}{ }_{8}=19.92, P=0.011$; household contents index, $\chi^{2}{ }_{10}=23.6, P=0.009$; father's education, $\chi^{2}{ }_{4}=12,65, P=0.013$ and no of siblings, $\chi^{2}{ }_{7}=17.34$, $P=0.015)$.

Furthermore, a log-linear model was fitted, and the outcome was much the same with independent effects on the principal factors fitted but with slightly different values: age (Wald $\chi^{2}{ }_{3}=17.22, P=0.001$ ), the number of siblings (Wald $\chi^{2}{ }_{7}=17.20, P=0.016$ ), father's education (Wald $\chi^{2}{ }_{4}=13.75, P=0.008$ ), household floor (Wald $\chi^{2}{ }_{8}=25.20, P=0.001$ ) and household contents index (Wald $\chi^{2}{ }_{10}=26.73, P=0.003$ ).

\section{Understanding/appreciation of parasitic infections}

Although our survey instrument included basic questions designed to assess individuals' understanding and appreciation of the importance of enteric parasitic infections, the vast majority of respondents were unable to offer any replies to our questions, and this aspect of the study was abandoned.

\section{Discussion}

The transmission of intestinal parasites among a population is dependent firstly on the presence of infected individuals, and then for species that employ the fecal-oral route, on poor sanitation.

Socioeconomic and behavioral factors in the population are also crucially important. In our study, we found that the prevalence of combined protozoan infections in the newly arrived immigrants to Qatar was significantly higher (12.1\%) than that among immigrants who had previously visited Qatar $(6.6 \%)$ and mostly had lived and worked in the city. The overall prevalence of helminth infections was lower than that of protozoan parasitic infections but the trend was in the same direction with $7.2 \%$ for the newly arrived and $4.9 \%$ for individuals who had previously visited Qatar. Analysis by univariate statistical models of the questionnaire completed by all subjects in the study revealed that personal and familial characteristics including religion, education, number of siblings and parent's educational background all played an important role in influencing the prevalence of combined protozoan infection. However, our data revealed that only the mother's educational level and the household contents index had a significant effect on the prevalence of enteric helminth infections, although no clear directional trend correlating with increasing or decreasing values of the index was identified. However, fitting univariate models does not allow the influence of confounding factors and their interactions to be identified, so in the second phase of our analysis we fitted all the significant effects from phase 1 into multifactorial models and combined these with age class and region of origin, which had been shown in our earlier paper to have had an influence on parasitic infections in these same individuals (14). This showed that many of the factors identified by univariate analysis are likely to have arisen through confounding interactions between fitted factors. The minimum sufficient models thus generated showed that the prevalence of combined helminth infections was influenced only by host age class and the mother's educational level. The prevalence of combined protozoa infections in contrast was affected by five factors that retained significance (age class, floor of house, household contents index, father's education, and number of siblings). 
An earlier study conducted in Sharjah investigated intestinal protozoan infection rates among both expatriates and locals, and the infection rate was reported as $7.7 \%$ (17). The prevelance of protozoan infection in our study was higher at $11.7 \%$. However, the prevalence of helminth infections in our study was marginally lower at $7.0 \%$, and lower also compared to similar studies in the region $(8,18-20)$. In addition, $17.8 \%$ of the study population carried at least one of the species (helminths + protozoa combined) that were identified. The prevalence of both combined helminth $(7.2 \%)$ and combined protozoan (12.15\%) infections was higher in immigrants who arrived in Qatar for the first time.

Soil-transmitted helminth (STH) infections continue to plague large parts of the world with India a significant contributor to the burden of disease (21). STH infections are a significant health problem in Qatar given the huge number of immigrants from India and Nepal. In our earlier analyses of the prevalence of parasitic infections and their temporal trends among settled immigrants in Qatar (13), immigrants from western Asia were observed to harbor the highest prevalence of helminth infections whereas immigrants from most other regions lost their helminth burdens almost completely after acquiring residency permits. The prevalence of helminth infections among long-term residents recorded in the period from 2005 to 2008, and then in subsequent years (2009-2011) showed a clear trend of declining prevalence. In the current study, the lowest prevalence was observed for helminth infections among immigrants who had visited previously (4.9\%). The clear trend of declining prevalence of intestinal parasitic infections has been reported previously as evidence of the success of Qatar's policies (22), which demands that newcomers wishing to work and live in Qatar must undergo health mandatory checks to receive a Work Residence Permit. In addition, the efforts to introduce the usage of efficient latrines instead of open defecation, mass deworming programs and improvements in water quality and sanitation in countries, where intestinal parasitic infections are endemic and which are the sources of the immigrant labour force in Qatar, have led to a reduction in the prevalence of these infections, as for example in India.. A conducive climate for helminth transmission, rapid and unplanned urbanization, social practices of open defecation and lack of community education and sanitation are some of the factors, which have impeded control of parasitic infections in India in the past (23). However, India has undertaken two massive deworming programs, one starting in the year 2000 where a single dose of Albendazole and DEC was administered to communities in the filarial-endemic regions and another in year 2015 covering 241 million children for the treatment of STH infections $(24,25)$. These have been very successful in reducing the prevalence of helminth infections in the country $(24,25)$.

In this study, a relatively high prevalence of protozoan parasitic infections (15\%) was initially found in univariate models to be associated with the Hindu religion, but the influence of religion was not retained in models that took into account other factors, and is likely therefore to be a consequence of the confounding effect of other markers that reflect the subjects living condtions in their country of origin . Our finding might be due to the fact that the Hindu community are composed of India and Nepalese nationals (26), among who protozoan infections are endemic. On the other hand, no significant difference in the prevalence of helminth infections was observed between subjects practicing different religions, which may be due to massive deworming programs conducted in endemic countries. 
In our study, we observed that the individual's educational level and that of their parents also had an important influence on the prevalence of protozoan infections. Prevalence was highest among uneducated subjects $(15.2 \%)$ and also among those whose parents were illiterate ( $14.6 \%$ in both cases) and this was a highly significant finding. There was also a trend of decreasing prevalence with increasing level of education. Other studies have shown also that a mother's literacy is an important socio-economic factor influencing parasite prevalence (27-30). Another study has reported similar results to our study (31), with increasing parent's educational level correlating with declining prevalence of protozoan infections. We found a similar trend when examining the parents' occupational levels, the prevalence of protozoan infections declining consistently with increasing father's occupational level from no occupation (12.6\%), blue collar worker (11.9\%) and then white collar worker (5.3\%). A similar continuous reduction in prevalence was observed also with the mother's occupational level from no occupation $(12.1 \%)$ to white collar worker (4.2\%). In contrast, our analysis found no significant effects of occupational level on the prevalence of helminth infections, although there was a somewhat surprising finding in relation to the mother's educational level, but this was not consistent with increasing level of education. The highest prevalence of helminth infections was among the offspring of graduates.

In our analysis of the influence of environmental factors in the country of origin on protozoan and helminth infections, we observed that in general large families were more prone to infection. Although across the seven levels of house occupants detailed in the Table 2, there were no significant differences, it is nevertheless interesting to note that helminth and protozoan infections were least prevalent among people living alone or in couples. Notably, the prevalence of protozoan infections increased from just $3.4 \%$ among people living alone or in couples, to over $10 \%$ in all other cases and a maximum of $13.7 \%$ in the case of 5 occupants in a household. Our results are consistent with Halpenny et al (32) who found that the large families (with more than three children) were more likely to experience high prevalence of intestinal parasitic infections and higher co-infection patterns with multiple species, and these are likely to be attributable to overcrowding conditions in households (32). In addition, we found the highest prevalence of protozoan infections among people who lived in houses with only soil as the floor (18.9\%). Considering other possible household deficiencies that may enhance transmission of parasites between household inhabitants, and hence lead to higher prevalence, water and sanitization are two such key components. Access to clean water and efficient sanitary facilities within or in proximity to the household are essential to prevent deleterious effects on the health of inhabitants. In our study, the prevalence of protozoan infections was highest among individuals whose only supply of drinking was directly from a local river (16.7\%), or who exploited water from an uncovered well (13.4\%). However, perhaps unexpectedly, even those who had access to a tap indoors, were also subject to a relatively high risk of protozoan infection, in this case being $13.6 \%$, which indicates perhaps that the water supplies in these countries are contaminated. Interestingly those who relied primarily on bottled water and/or used a covered well, were less likely to be infected. The prevalence of helminth infections was also relatively high among individuals drinking river water (9.3\%).

The prevalence and control of STH and protozoan infections are inextricably linked to water quality, sanitation, hygiene practices and the socio-economic status of communities in regions where these 
parasites are endemic (33). Studies have shown that improved water quality, efficient sanitary facilities and good hygiene practice, all contribute significantly to preventing diarrhea, morbidity and mortality caused by protozoa and soil transmitted helminth in low- and middle-income countries (34). Therefore, household access to clean tap water, safe disposal of excreta (for example use of flushing toilets instead of open defecation) and education about good hygiene practice are crucially important for targeted interventions aiming to reduce the incidence of intestinal parasitic infections $(33,35,36)$. The vulnerability of drinking water supply systems to contamination by pathogens and the consequent increase of risk of waterborne diseases have been highlighted in several studies $(37,38)$. In addition, the protection of drinking water from these protozoa is a serious problem for water supply organizations around the world. Cryptosporidium and Giardia remain as the two most important water pathogens that could not be eradicated until relatively recently (34). Giardia is an anaerobic flagellated protozoa capable of encysting through a complex process of cyst wall formation (39), with this infective form being resistant to common disinfection controls such as chlorine and chloramines (40).

Since the intestinal helminths and protozoa studied in the current work are all dependent on fecal-oral transmission, the proper, safe and efficient management of feces and its disposal are key issues. When the surrounding environment is contaminated with feces, the magnitude of the problem may seem overwhelming (41-44). Pit latrines are often recommended as an important step away from open defecation in the bush, but in our study, we observed that $13.9 \%$ of individuals who use pit latrines in their home country suffered from protozoan infection, a figure that is significantly higher than the prevalence among those using flushing toilets and even open defecation. Throughout the world, there is a big difference in the coverage of toilets. Approximately 1.77 billion people around the world use pit latrines as the primary means of sanitation. Pit latrines are the simplest and most inexpensive form of improved sanitation, but they have to be maintained carefully to avoid infections. Pit latrines usually lack a physical barrier, such as concrete, between stored excrement and soil and/or groundwater (45). In some countries where pit latrines are common, more than two billion people use groundwater as a source of drinking water (45). Therefore, contaminants from pit latrines can also enter groundwater and create a threat to human health.

Our study is the first comprehensive study to address the issue of parasitic prevalence in an apparently healthy expatriate population in Qatar. However, our study suffered from certain limitations. Firstly, laboratory diagnosis of IPI was based on a single stool examination, which could have underestimated the prevalence, as optimal laboratory diagnosis of IPIs requires the examination of at least three stool specimens collected over several days (46), but clearly this was just not possible in our study. However, more recent studies have suggested that one or two stool samples will detect up to $90 \%$ of the protozoa present $(47,48)$. Secondly, the scarcity of figures from the local community to compare with expatriate data.

\section{Conclusion}


The increased prevalence of protozoan infections among migrant workers in Qatar over recent years (13) raises some concerns. In contrast to the helminth infections which as adjudged by the current data appear be increasingly well controlled among immigrants prior to their arrival in Qatar, as adjudged by the current data, protozoan infections among new arrivals appear to be increasing, at least in the short-term. Our work provides useful benchmark information for prioritizing and enlightening the targeting of interventions. In addition, it emphasizes the importance of regular checks for intestinal protozoan infections and subsequent treatment with anti-protozoal agents prior to arrival. We believe that this will be a highly desirable course of action for the future, and we strongly recommend that Qatar's health authorities implement such measures in the near future.

\section{Declarations}

\section{Funding}

This publication was made possible by a National Priority Research Program grant number NPRP8-15563-313 from the Qatar National Research Fund (http://www.qnrf.org/), a member of Qatar Foundation.

\section{Acknowledgements}

We would like to thank all the technical staff of the Medical Commission, Ministry of Public Health and to the Biomedical Research Center at Qatar University for providing the facilities for this work.

\section{Author contributions}

Conceptualization: AI MAM; Data curation: JMB MAM; Formal analysis: NY JMB; Funding acquisition: MAM; Investigation: MAM Al; Methodology: NY JMB MAM; Project administration: AI MAM; Resources: NY MAM; Software: MAM JMB; Supervision: AI MAM; Validation: JMB MAM; Visualization: NY JMB; Writing - original draft: NY JMB MAM; Writing - review \& editing: MAM JMB.

\section{Disclaimer}

The contents of this report are solely the responsibility of the authors and do not necessarily represent the official views of Qatar University and Qatar National Research Fund.

\section{Conflict of interest}

The authors have declared that no competing interests exist.

\section{References}

1. Brooker S, Clements AC, Bundy DA. Global epidemiology, ecology and control of soil-transmitted helminth infections. Advances in parasitology. 2006;62:221-61. 
2. Dachs JN, Ferrer M, Florez CE, Barros AJ, Narvaez R, Valdivia M. Inequalities in health in Latin America and the Caribbean: descriptive and exploratory results for self-reported health problems and health care in twelve countries. Revista panamericana de salud publica = Pan American journal of public health. 2002;11(5-6):335-55.

3. Savioli L, Albonico M, Engels D, Montresor A. Progress in the prevention and control of schistosomiasis and soil-transmitted helminthiasis. Parasitology international. 2004;53(2):103-13.

4. Celiksoz A, Guler N, Guler G, Oztop AY, Degerli S. Prevalence of intestinal parasites in three socioeconomically-different regions of Sivas, Turkey. Journal of health, population, and nutrition. 2005;23(2):184-91.

5. Woh PY, Thong KL, Behnke JM, Lewis JW, Mohd Zain SN. Evaluation of basic knowledge on food safety and food handling practices amongst migrant food handlers in Peninsular Malaysia. Food Control. 2016;70:64-73.

6. Sahimin N, Lim YA, Ariffın F, Behnke JM, Lewis JW, Mohd Zain SN. Migrant Workers in Malaysia: Current Implications of Sociodemographic and Environmental Characteristics in the Transmission of Intestinal Parasitic Infections. PLoS neglected tropical diseases. 2016;10(11):e0005110.

7. Andargie G, Kassu A, Moges F, Tiruneh M, Huruy K. Prevalence of bacteria and intestinal parasites among food-handlers in Gondar town, northwest Ethiopia. Journal of health, population, and nutrition. 2008;26(4):451-5.

8. Sharif M, Daryani A, Kia E, Rezaei F, Nasiri M, Nasrolahei M. Prevalence of intestinal parasites among food handlers of Sari, Northern Iran. Revista do Instituto de Medicina Tropical de Sao Paulo. 2015;57(2):139-44.

9. Wang LC. Changing patterns in intestinal parasitic infections among Southeast Asian laborers in Taiwan. Parasitology research. 2004;92(1):18-21.

10. Zaglool DA, Khodari YA, Othman RAM, Farooq MU. Prevalence of intestinal parasites and bacteria among food handlers in a tertiary care hospital. Nigerian medical journal : journal of the Nigeria Medical Association. 2011;52(4):266-70.

11. Takalkar AA, Madhekar NS, Kumavat AP, Bhayya SM. Prevalence of intestinal parasitic infections amongst food handlers in hotels and restaurants in Solapur city. Indian journal of public health. 2010;54(1):47-8.

12. Kheirandish F, Tarahi MJ, Ezatpour B. Prevalence of intestinal parasites among food handlers in Western Iran. Revista do Instituto de Medicina Tropical de Sao Paulo. 2014;56(2):111-4.

13. Abu-Madi MA, Behnke JM, Doiphode SH. Intestinal parasitic infections among long-term-residents and settled immigrants in Qatar in the period 2005 to 2011. The American journal of tropical medicine and hygiene. 2013;88(6):1185-95.

14. Abu-Madi MA, Behnke JM, Ismail A, Boughattas S. Assessing the burden of intestinal parasites affecting newly arrived immigrants in Qatar. Parasit Vectors. 2016;9(1):619.

15. Abu-Madi M, Boughattas S, Behnke JM, Sharma A, Ismail A. Coproscopy and molecular screening for detection of intestinal protozoa. Parasites \& vectors. 2017;10(1):414-. 
16. Abu-Madi M, Behnke JM, Sharma A, Bearden R, Al-Banna N. Prevalence of Virulence/Stress Genes in Campylobacter jejuni from Chicken Meat Sold in Qatari Retail Outlets. PLoS One. 2016;11(6):e0156938.

17. Dafalla AIA, Almuhairi SASO, AlHosani MHJ, Mohamed MY, Alkous MIA, AIAzzawi MA, et al. Intestinal parasitic infections among expatriate workers in various occupations in Sharjah, United Arab Emirates. Revista do Instituto de Medicina Tropical de Sao Paulo. 2017;59:e82-e.

18. Abahussain N. Prevalence of intestinal parasites among expatriate workers in Al-Khobar, Saudi Arabia. Middle East J Fam Med. 2005.

19. Taha HA, Soliman MI, Banjar SA. Intestinal parasitic infections among expatriate workers in AlMadina Al-Munawarah, Kingdom of Saudi Arabia. Tropical biomedicine. 2013;30(1):78-88.

20. Astal Z. Epidemiological survey of the prevalence of parasites among children in Khan Younis governorate, Palestine. Parasitology research. 2004;94(6):449-51.

21. Lobo DA, Velayudhan R, Chatterjee P, Kohli H, Hotez PJ. The neglected tropical diseases of India and South Asia: review of their prevalence, distribution, and control or elimination. PLoS neglected tropical diseases. 2011;5(10):e1222-e.

22. Government Qe. Medical Commission Procedures.

23. Salam N, Azam S. Prevalence and distribution of soil-transmitted helminth infections in India. BMC Public Health. 2017;17(1):201-.

24. Awasthi S, Peto R, Read S, Richards SM, Pande V, Bundy D, et al. Population deworming every 6 months with albendazole in 1 million pre-school children in North India: DEVTA, a cluster-randomised trial. Lancet. 2013;381(9876):1478-86.

25. Ganguly S, Barkataki S, Karmakar S, Sanga P, Boopathi K, Kanagasabai K, et al. High prevalence of soil-transmitted helminth infections among primary school children, Uttar Pradesh, India, 2015. Infect Dis Poverty. 2017;6(1):139-.

26. Hotez PJ. The World's Great Religions and Their Neglected Tropical Diseases. PLoS neglected tropical diseases. 2016;10(7):e0004544-e.

27. Mamatha G, K M. Awareness of Mothers of under Five Year Children Regarding Round Worm Infestation, its Prevention and Management: A Descriptive Analysis. International Journal of Nursing Education. 2014.

28. Zonta ML, Oyhenart EE, Navone GT. Socio-environmental variables associated with malnutrition and intestinal parasitoses in the child population of Misiones, Argentina. American journal of human biology : the official journal of the Human Biology Council. 2014;26(5):609-16.

29. Buor D. Mothers' education and childhood mortality in Ghana. Health policy (Amsterdam, Netherlands). 2003;64(3):297-309.

30. Quihui L, Valencia ME, Crompton DWT, Phillips S, Hagan P, Morales G, et al. Role of the employment status and education of mothers in the prevalence of intestinal parasitic infections in Mexican rural schoolchildren. BMC Public Health. 2006;6:225-. 
31. Bahmani P, Maleki A, Sadeghi S, Shahmoradi B, Ghahremani E. Prevalence of Intestinal Protozoa Infections and Associated Risk Factors among Schoolchildren in Sanandaj City, Iran. Iranian journal of parasitology. 2017;12(1):108-16.

32. Halpenny CM, Koski KG, Valdes VE, Scott ME. Prediction of child health by household density and asset-based indices in impoverished indigenous villages in rural Panama. Am J Trop Med Hyg. 2012;86(2):280-91.

33. Strunz EC, Addiss DG, Stocks ME, Ogden S, Utzinger J, Freeman MC. Water, sanitation, hygiene, and soil-transmitted helminth infection: a systematic review and meta-analysis. PLoS medicine. 2014;11(3):e1001620.

34. Omarova A, Tussupova K, Berndtsson R, Kalishev M, Sharapatova K. Protozoan Parasites in Drinking Water: A System Approach for Improved Water, Sanitation and Hygiene in Developing Countries. International journal of environmental research and public health. 2018;15(3):495.

35. Ziegelbauer K, Speich B, Mausezahl D, Bos R, Keiser J, Utzinger J. Effect of sanitation on soiltransmitted helminth infection: systematic review and meta-analysis. PLoS medicine. 2012;9(1):e1001162.

36. Boisson S, Sosai P, Ray S, Routray P, Torondel B, Schmidt WP, et al. Promoting latrine construction and use in rural villages practicing open defecation: process evaluation in connection with a randomised controlled trial in Orissa, India. BMC research notes. 2014;7:486.

37. Nescerecka A, Rubulis J, Vital M, Juhna T, Hammes F. Biological instability in a chlorinated drinking water distribution network. PloS one. 2014;9(5):e96354-e.

38. Rodriguez-Alvarez MS, Weir MH, Pope JM, Seghezzo L, Rajal VB, Salusso MM, et al. Development of a relative risk model for drinking water regulation and design recommendations for a peri urban region of Argentina. International journal of hygiene and environmental health. 2015;218(7):627-38.

39. Rivero MR, Vranych CV, Bisbal M, Maletto BA, Ropolo AS, Touz MC. Adaptor protein 2 regulates receptor-mediated endocytosis and cyst formation in Giardia lamblia. The Biochemical journal. 2010;428(1):33-45.

40. Betancourt WQ, Rose JB. Drinking water treatment processes for removal of Cryptosporidium and Giardia. Veterinary parasitology. 2004;126(1-2):219-34.

41. Caccio SM, De Giacomo M, Aulicino FA, Pozio E. Giardia cysts in wastewater treatment plants in Italy. Applied and environmental microbiology. 2003;69(6):3393-8.

42. Fayer R. Cryptosporidium: a water-borne zoonotic parasite. Veterinary parasitology. 2004;126(12):37-56.

43. Montemayor M, Valero F, Jofre J, Lucena F. Occurrence of Cryptosporidium spp. oocysts in raw and treated sewage and river water in north-eastern Spain. Journal of applied microbiology. 2005;99(6):1455-62.

44. Ruecker NJ, Braithwaite SL, Topp E, Edge T, Lapen DR, Wilkes G, et al. Tracking host sources of Cryptosporidium spp. in raw water for improved health risk assessment. Applied and environmental microbiology. 2007;73(12):3945-57. 
45. Graham JP, Polizzotto ML. Pit latrines and their impacts on groundwater quality: a systematic review. Environmental health perspectives. 2013;121(5):521-30.

46. Branda JA, Lin TY, Rosenberg ES, Halpern EF, Ferraro MJ. A rational approach to the stool ova and parasite examination. Clin Infect Dis. 2006;42(7):972-8.

47. Haque R. Human intestinal parasites. Journal of health, population, and nutrition. 2007;25(4):387-91.

48. Marti $\mathrm{H}$, Koella JC. Multiple stool examinations for ova and parasites and rate of false-negative results. J Clin Microbiol. 1993;31(11):3044-5.

\section{Tables}

Table 1. Prevalence of intestinal helminths and protozoan parasites in the study group. Data from ref 14. 


\begin{tabular}{|c|c|}
\hline & Prevalence (95\% confidence limits) \\
\hline Helminths & \\
\hline Ascaris lumbricoides & $1.8(1.29-2.38)$ \\
\hline Hookworms & $3.5(2.84-4.36)$ \\
\hline Trichuris trichiura & $1.4(0.98-1.96)$ \\
\hline Strongyloides stercoralis & $0.4(0.22-0.79)$ \\
\hline Taenia spp. & $0.1(0.01-0.29)$ \\
\hline Hymenolepis nana & $0.4(0.19-0.74)$ \\
\hline Enterobius vernicularis & $0.1(0.02-0.35)$ \\
\hline All helminths combined & $7.0(6.03-8.05)$ \\
\hline Protozoa & \\
\hline Blastocystis hominis & $5.5(4.61-6.41)$ \\
\hline Chilomastix mesnili & $0.1(0.02-0.35)$ \\
\hline Endolimax nana & $3.1(2.48-3.92)$ \\
\hline Entamoeba coli & $2.2(1.67-2.88)$ \\
\hline Entamoeba hartmanni & $0.4(0.22-0.79)$ \\
\hline Entamoeba histolytica/dispar & $0.9(0.59-1.39)$ \\
\hline Giardia duodenalis & $2.3(1.77-3.02)$ \\
\hline Iodamoeba butschlii & $0.3(0.11-0.58)$ \\
\hline All protozoa combined & $11.7(10.4-12.93)$ \\
\hline Helminths and protozoa combined & $17.8(16.28-19.28)$ \\
\hline
\end{tabular}




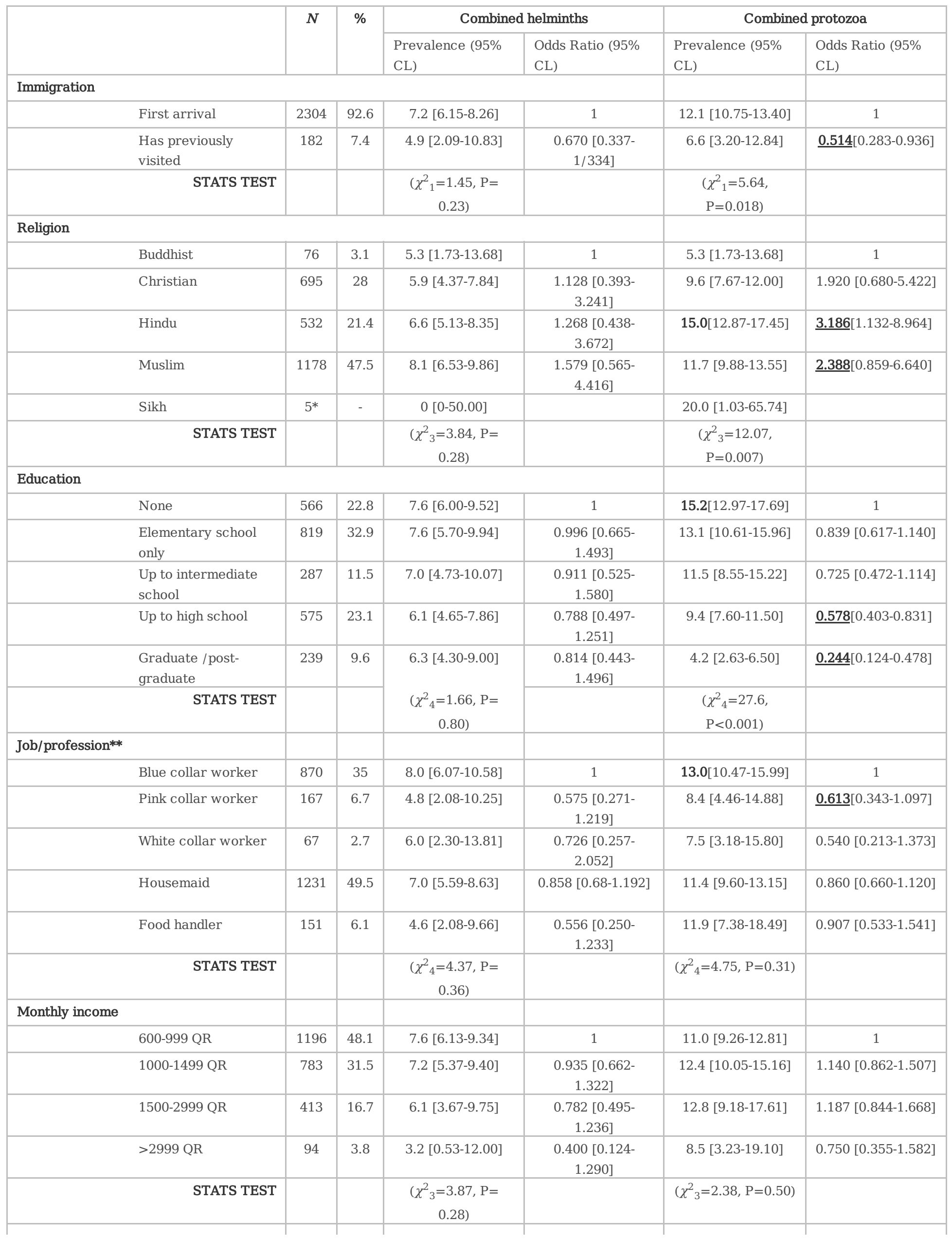




\begin{tabular}{|c|c|c|c|c|c|c|}
\hline \multicolumn{7}{|l|}{ No of siblings } \\
\hline 0 & 82 & 3.3 & 3.7 [0.82-11.79] & 1 & $11.0[5.11-21.35]$ & 1 \\
\hline 1 & 240 & 9.7 & $5.8[3.94-8.50]$ & $\underline{1.631}[0.457-5.826]$ & $12.1[9.28-15.53]$ & $1.115[0.504-2.466]$ \\
\hline 2 & 431 & 17.3 & 6.7 [4.14-10.67] & $\underline{1.900}[0.565-6.389]$ & $12.1[8.42-16.81]$ & 1.113 [0.525-2.357] \\
\hline 3 & 439 & 17.7 & $5.7[3.34-9.45]$ & $\underline{1.590}[0.469-5.394]$ & 9.1 [5.99-13.62] & $0.813[0.378-1.747]$ \\
\hline 4 & 401 & 16.1 & $8.2[5.43-12.32]$ & $\underline{\mathbf{2 . 3 6 1}}[0.707-7.893]$ & 14.5 [10.60-19.30] & $1.372[0.650-2.893]$ \\
\hline 5 & 309 & 12.4 & 8.1 [5.61-11.57] & $\underline{2.318}[0.682-7.877]$ & 7.8 [5.34-11.18] & $0.683[0.304-1.532]$ \\
\hline 6 & 221 & 8.9 & 8.6 [6.34-11.57] & $\underline{\mathbf{2 . 4 7 7}}[0.713-8.603]$ & 16.3[13.13-19.96] & $1.578[0.724-3.440]$ \\
\hline$>6^{* * *}$ & 363 & 14.6 & 7.4 [4.90-11.12] & $\underline{2.116}[0.626-7.151]$ & 11.6 [8.28-15.82] & $1.061[0.495-2.277]$ \\
\hline STATS TEST & & & $\left(\chi^{2}{ }_{7}=5.8, \mathrm{P}=0.56\right)$ & & $\begin{array}{l}\left(\chi_{7}^{2}=15.2\right. \\
\mathrm{P}=0.033)\end{array}$ & \\
\hline \multicolumn{7}{|l|}{ Father's education } \\
\hline None & 1550 & 62.3 & $7.1[5.82-8.38]$ & 1 & $14.6[12.82-16.34]$ & 1 \\
\hline $\begin{array}{l}\text { Elementary school } \\
\text { only }\end{array}$ & 495 & 19.9 & $8.1[5.02-12.75]$ & $\begin{array}{l}1.151[0.789- \\
1.678]\end{array}$ & $7.3[4.38-11.74]$ & $\underline{\mathbf{0 . 4 5 9}}[0.318-0.663]$ \\
\hline $\begin{array}{l}\text { Up to intermediate } \\
\text { school }\end{array}$ & 109 & 4.4 & $9.2[5.71-14.32]$ & $\begin{array}{l}1.322[0.671- \\
2.607]\end{array}$ & $7.3[4.33-12.08$ & $\underline{\mathbf{0 . 4 6 4}}[0.223-0.966]$ \\
\hline Up to high school & 225 & 9.1 & $4.0[2.51-6.20]$ & $\underline{\mathbf{0 . 5 4 5}}[0.272-1.092]$ & 5.8 [3.93-8.34] & $\underline{\mathbf{0 . 3 5 9}}[0.202-0.640]$ \\
\hline $\begin{array}{l}\text { Graduate / post- } \\
\text { graduate }\end{array}$ & 107 & 4.3 & $5.6[3.07-9.85]$ & $\begin{array}{l}0.778[0.334- \\
1.812]\end{array}$ & 6.5 [3.76-11.02] & $\underline{\mathbf{0 . 4 1 0}}[0.188-0.894]$ \\
\hline STATS TEST & & & $\begin{array}{c}\left(\chi_{4}^{2}=5.57, \mathrm{P}=\right. \\
0.23)\end{array}$ & & $\begin{array}{l}\left(\chi_{4}^{2}=37.0\right. \\
\mathrm{P}<0.001)\end{array}$ & \\
\hline \multicolumn{7}{|l|}{ Father's occupation/profession } \\
\hline None & 1160 & 46.9 & 6.8 [5.39-8.49] & 1 & $12.6[10.68-14.50]$ & 1 \\
\hline Blue collar worker & 1106 & 44.7 & $7.4[5.90-9.20]$ & $\begin{array}{c}1.096[0.795- \\
1.510]\end{array}$ & 11.9 [10.02-13.85] & $0.941[0.732-1.210]$ \\
\hline White collar worker & 207 & 8.4 & $6.3[4.38-8.82]$ & $\begin{array}{c}0.917[0.500- \\
1.681]\end{array}$ & $5.3[3.61-7.69]$ & $\underline{\mathbf{0 . 3 9 0}}[0.207-0.733]$ \\
\hline Unknown $^{* * * *}$ & 13 & & & & & \\
\hline STAT TEST & & & $\begin{array}{c}\left(\chi_{2}^{2}=0.52, \mathrm{P}=\right. \\
0.77)\end{array}$ & & $\begin{array}{c}\left(\chi_{2}^{2}=10.93\right. \\
P=0.004)\end{array}$ & \\
\hline \multicolumn{7}{|l|}{ Mother's education } \\
\hline None & 1703 & 68.5 & 6.9 [5.67-8.07] & 1 & $14.6[12.33-15.62]$ & 1 \\
\hline $\begin{array}{l}\text { Elementary school } \\
\text { only }\end{array}$ & 440 & 17.7 & 9.5 [6.31-14.08] & $\underline{1.430}[0.989-2.069]$ & 7.5 [4.72-11.68] & $\underline{\mathbf{0 . 4 4 9}}[0.341-0.730]$ \\
\hline $\begin{array}{l}\text { Up to intermediate } \\
\text { school }\end{array}$ & 81 & 3.3 & 3.7 [0.85-11.78] & $\begin{array}{l}0.521[0.162- \\
1.677]\end{array}$ & 8.6 [3.60-18.32] & 0.582 [0.265-1.279] \\
\hline Up to high school & 201 & 8.1 & $3.5[2.15-5.45]$ & $\underline{\mathbf{0 . 4 8 9}}[0.225-1.064]$ & $4.5[2.95-6.65]$ & $\underline{\mathbf{0 . 2 8 9}}[0.146-0.571]$ \\
\hline $\begin{array}{l}\text { Graduate / post- } \\
\text { graduate }\end{array}$ & 61 & 2.5 & 9.8 [4.93-18.17] & $\begin{array}{c}1.479[0.624- \\
3.506]\end{array}$ & 4.9 [1.77-12.06] & $\underline{\mathbf{0 . 3 1 8}}[0.099-1.024]$ \\
\hline STATS TEST & & & $\begin{array}{c}\left(\chi^{2}{ }_{4}=10.92\right. \\
\mathrm{P}=0.027)\end{array}$ & & $\begin{array}{l}\left(\chi_{4}^{2}=33.7\right. \\
\mathrm{P}<0.001)\end{array}$ & \\
\hline \multicolumn{7}{|l|}{ Mother's Job/profession } \\
\hline None & 2196 & 88.3 & 7.0 [5.94-8.08] & 1 & $12.1[10.70-13.43]$ & 1 \\
\hline Blue collar worker & 218 & 8.8 & $6.0[4.10-8.53]$ & $0.841[0.469-$ & 10.1 [7.58-13.19] & 0.818 [0.517-1.294] \\
\hline
\end{tabular}




\begin{tabular}{|c|c|c|c|c|c|c|}
\hline & & & & $1.508]$ & & \\
\hline White collar worker & 72 & 2.9 & $11.1[5.45-20.71]$ & $\begin{array}{c}1.657[0.781- \\
3.520]\end{array}$ & $4.2[1.18-11.79]$ & $\underline{\mathbf{0 . 3 1 7}}[0.099-1.014]$ \\
\hline STATS TEST & & & $\begin{array}{c}\left(\chi_{2}^{2}=0.52\right. \\
\mathrm{P}=0.77)\end{array}$ & & $\begin{array}{l}\left(\chi_{2}^{2}=5.95\right. \\
\mathrm{P}=0.051)\end{array}$ & \\
\hline
\end{tabular}

*Excluded from the analysis because sample size too small to be meaningful

**Occupation/Profession:

Blue collar: mechanics, masons, builders, car wash attendants, carpenters, cleaners, crane operators, drivers, electricians, fire fighters, fitters, gardeners, labourers, painters, plumbers, steel fixers and welders.

Pink collar: barbers, beauticians, butlers, grocers, hairdressers, life guards' merchandisers, nurses, safety officers/guards, sales persons, saloon workers, security guards and tailors.

White collar: accountants, cashiers, civil engineers, clerks, IT experts, office boys, receptionists, and secretaries.

Food handlers: bakers, butchers, chefs, cooks, kitchen assistants, waiters/waitresses.

Housemaids

*** This category ranged from 7 to 16 siblings.

**** missing information

The stats outputs that are significant are emphasized in bold, as is also the highest prevalence within the factor level

Table 3. The prevalence of helminths and protozoa in relation to environmental factors in country of origin. 


\begin{tabular}{|c|c|c|c|c|c|c|}
\hline & & & \multicolumn{2}{|c|}{ Combined Helminth } & \multicolumn{2}{|l|}{ Combined protozoa } \\
\hline & $N$ & $\%$ & Prevalence (95\% CL) & Odds Ratio (95\% CL) & Prevalence (95\% CL) & Odds Ratio (95\% CL) \\
\hline \multicolumn{7}{|l|}{ Ownership of home } \\
\hline Owned & 2306 & 92.7 & $7.2[6.18-8.30]$ & 1 & 18.0 [16.43-19.56] & 1 \\
\hline Rented & 180 & 7.2 & $4.4[1.77-10.06]$ & $\begin{array}{l}0.596[ \\
0.288- \\
1.231]\end{array}$ & $15.0[9.24-22.86]$ & $\begin{array}{l}0.804[ \\
0.527- \\
1.227]\end{array}$ \\
\hline STATS TEST & & & $\left(\chi_{1}^{2}=2.26, \mathrm{P}=0.77\right)$ & & $\left(\chi_{1}^{2}=0.24, \mathrm{P}=0.63\right)$ & \\
\hline \multicolumn{7}{|c|}{ No. of people living sharing house } \\
\hline 1 or 2 & 87 & 3.5 & 4.6 [1.20-13.59] & 1 & 3.4 [0.69-11.86] & 1 \\
\hline 3 & 398 & 16.0 & $6.5[4.08-10.24]$ & $\begin{array}{l}1.450[ \\
0.493- \\
4.267]\end{array}$ & 10.6 [7.25-14.93] & $\begin{array}{c}\frac{3.303}{1.000} \\
- \\
10.915]\end{array}$ \\
\hline 4 & 566 & 22.8 & $6.5[5.06-8.36]$ & $\begin{array}{l}1.451[ \\
0.504- \\
1.178]\end{array}$ & 11.8 [9.85-14.13] & $\begin{array}{c}\frac{3.760}{1.156-} \\
12.229]\end{array}$ \\
\hline 5 & 502 & 20.2 & $6.4[4.98-8.06]$ & $\begin{array}{l}1.413[ \\
0.487- \\
4.100]\end{array}$ & 13.7 [11.71-16.02] & $\begin{array}{c}\frac{\mathbf{4 . 4 6 2}[}{1.372-} \\
14.511]\end{array}$ \\
\hline 6 & 361 & 14.5 & $6.6[4.27-10.15]$ & $\begin{array}{l}1.478[ \\
0.499- \\
4.375]\end{array}$ & 12.2 [8.84-16.48] & $\begin{array}{c}\frac{3.886}{1.178} \\
- \\
12.827]\end{array}$ \\
\hline 7 or 8 & 347 & 13.9 & $10.1[7.08-14.04]$ & $\begin{array}{l}2.328[ \\
0.804 \\
6.735]\end{array}$ & 11.8 [8.57-15.97] & $\begin{array}{c}\text { 3.752[ } \\
1.134- \\
12.417 \\
]\end{array}$ \\
\hline 9 to 50 & 225 & 9.1 & 7.6 [5.41-10.39] & $\begin{array}{c}1.696[ \\
0.554 \\
5.190]\end{array}$ & 10.7 [8.07-13.88] & $\begin{array}{c}\frac{3.343}{0.980} \\
- \\
11.403]\end{array}$ \\
\hline STATS TEST & & & $\left(\chi_{6}^{2}=6.19, \mathrm{P}=0.40\right)$ & & $\left(\chi_{6}^{2}=10.47, \mathrm{P}=0.11\right)$ & \\
\hline \multicolumn{7}{|l|}{ No of rooms in house } \\
\hline 1 & 207 & 8.3 & 6.3 [4.38-8.8213] & 1 & 8.7 [6.47-11.58] & 1 \\
\hline 2 & 889 & 35.7 & $7.0[5.10-9.37]$ & $\begin{array}{l}1.119[ \\
0.603- \\
2.076]\end{array}$ & 11.6 [9.17-14.49] & $\begin{array}{l}1.376 \text { [ } \\
0.814- \\
2.327]\end{array}$ \\
\hline 3 & 739 & 29.7 & $7.7[5.92-9.96]$ & $\begin{array}{l}1.241[ \\
0.669- \\
2.326]\end{array}$ & 11.8 [9.55-14.40] & $\begin{array}{c}1.401[ \\
0.822 \\
- \\
2.387]\end{array}$ \\
\hline 4 & 407 & 16.4 & $6.9[4.32-10.71]$ & $\begin{array}{l}1.102[ \\
0.558- \\
2.177]\end{array}$ & $15.2[11.26-20.22]$ & $\begin{array}{c}1.887[ \\
1.084- \\
3.283 \\
]\end{array}$ \\
\hline
\end{tabular}




\begin{tabular}{|c|c|c|c|c|c|c|}
\hline 5 to 25 & 244 & 9.8 & 6.1 [4.18-8.89] & $\begin{array}{l}0.977[ \\
0.454- \\
2.105]\end{array}$ & 8.2 [5.91-11.27] & $\begin{array}{c}0.937[ \\
0.482- \\
1.824 \\
]\end{array}$ \\
\hline STATS TEST & & & $\left(\chi_{4}^{2}=1.02, \mathrm{P}=0.91\right)$ & & $\left(\chi_{4}^{2}=9.72, \mathrm{P}=0.045\right)$ & \\
\hline \multicolumn{7}{|l|}{ House construction } \\
\hline Earth \&mud & 247 & 9.9 & 6.9 [4.77-9.73] & 1 & 15.0 [11.83-18.72] & 1 \\
\hline Wood & 385 & 15.4 & $7.3[4.70-11.05]$ & $\begin{array}{c}1.061[ \\
0.568- \\
1.982 \\
]\end{array}$ & $10.1[6.97-14.34]$ & $\begin{array}{l}\frac{0.640}{0.395-} \\
1.035]\end{array}$ \\
\hline Bricks/stones & 782 & 31.5 & 7.7 [5.83-9.99] & $\begin{array}{c}1.124[ \\
0.643 \\
- \\
1.966 \\
]\end{array}$ & 12.9 [10.53-15.73] & $\begin{array}{l}0.842 \\
0.550- \\
1.265]\end{array}$ \\
\hline Concrete & 1057 & 42.5 & $6.3[4.91-8.05]$ & $\begin{array}{l}0.916[ \\
0.528- \\
1.589]\end{array}$ & 10.4 [8.57-12.25] & $\begin{array}{l}\frac{\mathbf{0 . 6 5 9}}{0.441} \\
0.985]\end{array}$ \\
\hline Metal & 15 & 0.6 & 20 [5.69-46.57] & $\begin{array}{c}3.382[ \\
0.870- \\
13.148 \\
]\end{array}$ & 20.0 [5.69-46.57] & $\begin{array}{c}1.419 \\
0.381- \\
5.272 \\
]\end{array}$ \\
\hline STATS TEST & & & $\left(\chi_{4}^{2}=3.99, \mathrm{P}=0.41\right)$ & & $\left(\chi_{4}^{2}=7.05, \mathrm{P}=0.13\right)$ & \\
\hline \multicolumn{7}{|l|}{ Floor of house } \\
\hline Soil & 424 & 17.1 & 8.0 [5.19-12.22] & 1 & $18.9[14.30-24.40]$ & 1 \\
\hline Sand & 173 & 6.9 & $6.9[3.51-13.11]$ & $\begin{array}{l}0.855[ \\
0.432- \\
1.693]\end{array}$ & 7.5 [3.83-13.93] & $\begin{array}{l}\frac{0.349}{0.189} \\
0.646]\end{array}$ \\
\hline Natural hard surface & 99 & 3.9 & $10.1[4.12-21.78]$ & $\begin{array}{l}1.289[ \\
0.614- \\
2.706]\end{array}$ & $4.0[0.75-13.67]$ & $\begin{array}{l}\underline{\mathbf{0 . 1 8 1}} \\
0.065 \\
0.507]\end{array}$ \\
\hline Straw/other overlay & 51 & 2.1 & 7.8 [3.67-15.18] & $\begin{array}{l}0.976[ \\
0.332- \\
2.873]\end{array}$ & $9.8[5.17-17.28]$ & $\begin{array}{l}0.467[ \\
0.180- \\
1.214]\end{array}$ \\
\hline Concrete/brick & 1513 & 60.9 & $6.7[5.42-7.93]$ & $\begin{array}{l}0.820[ \\
0.548- \\
1.230]\end{array}$ & 11.4 [9.83-13.04] & $\begin{array}{l}\underline{\mathbf{0 . 5 5 5}} \\
0.415 \\
0.742\end{array}$ \\
\hline Wooden floor boards & 100 & 4.0 & $6.0[2.65-12.38]$ & $\begin{array}{l}0.732[ \\
0.299- \\
1.795]\end{array}$ & 4.0 [1.38-9.85] & $\begin{array}{l}\frac{0.179}{0.064} \\
0.500]\end{array}$ \\
\hline
\end{tabular}




\begin{tabular}{|c|c|c|c|c|c|c|}
\hline Linoleum & 62 & 2.5 & $9.7[4.80-18.08]$ & $\begin{array}{l}1.229[ \\
0.494- \\
3.059]\end{array}$ & 12.9 [6.94-21.86] & $\begin{array}{l}0.637[ \\
0.292- \\
1.392]\end{array}$ \\
\hline Carpet & 6 & 0.2 & 0.0 [0-41.13] & 0 & 0.0 [0.0-41.13] & \\
\hline Tiles & 58 & 2.3 & $3.4[0.99-9.64]$ & $\begin{array}{c}0.410[ \\
0.096- \\
1.752 \\
]\end{array}$ & $5.2[1.98-12.15]$ & $\begin{array}{l}\frac{\mathbf{0 . 2 3 5}}{0.072-} \\
0.769]\end{array}$ \\
\hline STATS TEST & & & $\left(\chi^{2}{ }_{8}=5.26, \mathrm{P}=0.73\right)$ & & $\left(\chi^{2}{ }_{8}=41.10, \mathrm{P}<0.001\right)$ & \\
\hline \multicolumn{7}{|l|}{ Toilet } \\
\hline Flushing & 820 & 32.9 & $7.2[5.37-9.51]$ & 1 & 7.6 [5.69-9.93] & 1 \\
\hline Pit latrine & 1585 & 63.8 & $6.9[5.63-8.12]$ & $\begin{array}{c}0.953[ \\
0.686- \\
1.323 \\
]\end{array}$ & 13.9 [12.24-15.65] & $\begin{array}{c}\frac{1.981}{1.474-} \\
2.661 \\
]\end{array}$ \\
\hline None/Bush & 81 & 3.3 & 8.6 [3.60-18.32] & $\begin{array}{l}1.220[ \\
0.538- \\
2.768]\end{array}$ & $8.6[3.60-18.32]$ & $\begin{array}{c}1.156[ \\
0.511- \\
2.618 \\
]\end{array}$ \\
\hline STATS TEST & & & $\left(\chi_{2}^{2}=0.39, \mathrm{P}=0.82\right)$ & & $\left(\chi_{2}^{2}=23.43, \mathrm{P}<0.001\right)$ & \\
\hline \multicolumn{7}{|c|}{ Household contents index } \\
\hline 0 & 385 & 15.5 & $9.4[6.37-13.5]$ & 1 & 16.1 [12.11-20.97] & 1 \\
\hline 1 & 413 & 16.7 & 9.0 [5.96-13.28] & $\begin{array}{c}0.954[ \\
0.589- \\
1.544 \\
]\end{array}$ & $11.1[7.67-15.71]$ & $\begin{array}{c}\underline{\mathbf{0 . 6 5 3}}\left[\begin{array}{c}0.432- \\
0.984 \\
]\end{array}\right. \\
\end{array}$ \\
\hline 2 & 824 & 33.1 & $5.7[4.1-7.83]$ & $\begin{array}{l}\underline{\mathbf{0 . 5 8 6}} \\
0.373- \\
0.922]\end{array}$ & 14.9 [12.3-17.94] & $\begin{array}{c}0.914[ \\
0.654 \\
- \\
1.275 \\
]\end{array}$ \\
\hline 3 & 295 & 11.9 & $5.4[3.49-8.31]$ & $\begin{array}{c}\underline{\mathbf{0 . 5 5 6}} \\
0.302- \\
1.203 \\
]\end{array}$ & $8.8[6.27-12.31]$ & 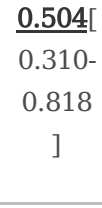 \\
\hline 4 & 205 & 8.2 & $7.3[5.26-9.98]$ & $\begin{array}{c}0.765[ \\
0.409- \\
1.434 \\
]\end{array}$ & 4.9 [3.27-7.15] & $\begin{array}{c}\mathbf{0 . 2 6 7} \\
0.134 \\
-0.533 \\
]\end{array}$ \\
\hline 5 & 95 & 3.8 & $8.4[3.15-19.05]$ & $\begin{array}{c}0.891[ \\
0.400- \\
1.987 \\
]\end{array}$ & $6.3[1.94-16.6]$ & $\begin{array}{c}\underline{\mathbf{0 . 3 5 1}}\left[\begin{array}{c}0.147- \\
0.839 \\
]\end{array}\right.\end{array}$ \\
\hline 6 & 67 & 2.6 & $11.9[6.3-21.17]$ & $\begin{array}{c}1.315[ \\
0.582- \\
2.968 \\
]\end{array}$ & 7.5 [3.18-15.8] & $\begin{array}{c}\underline{0.420} \\
0.162- \\
1.087 \\
]\end{array}$ \\
\hline 7 & 48 & 1.9 & $0.0[0-10.78]$ & & $4.2[0.47-18.16]$ & $\frac{\mathbf{0 . 2 2 7}[}{0.054-}$ \\
\hline
\end{tabular}

Page 23/26 


\begin{tabular}{|c|c|c|c|c|c|c|}
\hline & & & & & & $\begin{array}{c}0.958 \\
]\end{array}$ \\
\hline 8 & 55 & 2.2 & $1.8[0.29-7.26]$ & $\begin{array}{c}\underline{\mathbf{0 . 1 8 0}}[ \\
0.024- \\
1.337 \\
]\end{array}$ & $1.8[0.29-7.26]$ & $\begin{array}{c}\underline{\mathbf{0 . 0 9 6}} \\
0.013- \\
0.710 \\
]\end{array}$ \\
\hline 9 & 63 & 2.5 & 4.8 [1.65-11.99] & $\begin{array}{c}0.485[ \\
0.145- \\
1.624 \\
\quad]\end{array}$ & 4.8 [1.65-11.99] & $\begin{array}{c}\underline{\mathbf{0 . 2 6 0}} \\
0.079- \\
0.857 \\
]\end{array}$ \\
\hline 10 & 36 & 1.4 & $11.1[4.37-24.28]$ & $\begin{array}{c}1.212[ \\
0.406- \\
3.621 \\
]\end{array}$ & $16.7[7.75-31.08]$ & $\begin{array}{c}1.042[ \\
0.416- \\
2.609 \\
]\end{array}$ \\
\hline STATS TEST & & & $\left(\chi^{2}{ }_{10}=22.58, \mathrm{P}=0.012\right)$ & & $\left(\chi_{10}^{2}=48.56, \mathrm{P}<0.001\right)$ & \\
\hline Provision of hous & vater & & & & & \\
\hline Inside tap & 1329 & 53.5 & $6.8[5.45-8.32]$ & 1 & 13.6 [11.78-15.46] & 1 \\
\hline Outside tap & 46 & 1.9 & 6.5 [1.31-20.39] & $\begin{array}{c}0.960[ \\
0.292- \\
3.157 \\
]\end{array}$ & $8.7[2.38-23.46]$ & $\begin{array}{c}0.605[ \\
0.214- \\
1.705 \\
\text { ] }\end{array}$ \\
\hline Shared tap & 27 & 1.1 & $3.7[0.19-18.12]$ & $\begin{array}{c}0.529[ \\
0.071- \\
3.947 \\
]\end{array}$ & $0.0[0.00-12.38]$ & \\
\hline Covered well & 126 & 5.1 & $8.7[5.19-14.24]$ & $\begin{array}{c}1.317[ \\
0.684- \\
2.534 \\
]\end{array}$ & $4.8[2.32-9.24]$ & $\begin{array}{c}\underline{0.317}[ \\
0.138- \\
0.731 \\
]\end{array}$ \\
\hline Uncovered well & 440 & 17.7 & $8.2[5.27-12.52]$ & $\begin{array}{c}1.227[ \\
0.819- \\
1.830 \\
]\end{array}$ & 13.4 [9.52-18.43] & $\begin{array}{c}0.982[ \\
0.716- \\
1.347 \\
]\end{array}$ \\
\hline Borehole & 164 & 6.6 & $6.1[2.99-11.72]$ & $\begin{array}{c}0.894[ \\
0.455- \\
1.755 \\
]\end{array}$ & $9.8[5.55-16.26]$ & $\begin{array}{c}0.686[ \\
0.400- \\
1.176 \\
]\end{array}$ \\
\hline River & 54 & 2.2 & $9.3[4.69-16.96]$ & $\begin{array}{l}1.405[ \\
0.547- \\
3.613]\end{array}$ & $16.7[10.21-25.74]$ & $\begin{array}{c}1.269[ \\
0.610- \\
2.639 \\
]\end{array}$ \\
\hline Bottled water & 300 & 12.1 & $6.3[4.18-9.42]$ & $\begin{array}{c}0.931 \text { [ } \\
0.558- \\
1.552 \\
\text { ] }\end{array}$ & $5.0[3.15-7.82]$ & $\begin{array}{c}\underline{\mathbf{0 . 3 3 4}}[ \\
0.194- \\
0.575 \\
]\end{array}$ \\
\hline \multicolumn{2}{|l|}{ STATS TEST } & & $\left(\chi^{2}{ }_{7}=2.9, \mathrm{P}=0.89\right)$ & & $\left(\chi^{2}{ }_{7}=38.22, \mathrm{P}<0.001\right)$ & \\
\hline \multicolumn{5}{|c|}{ Farmer cultivate food } & & \\
\hline
\end{tabular}




\begin{tabular}{|c|c|c|c|c|c|c|}
\hline No & 1646 & 66.2 & $7.2[5.92-8.42]$ & 1 & $12.7[11.09-14.31]$ & 1 \\
\hline Yes & 840 & 33.8 & $6.8[4.99-9.08]$ & $\begin{array}{c}0.943[ \\
0.679- \\
1.308 \\
]\end{array}$ & $9.6[7.49-12.28]$ & $\begin{array}{c}\underline{\mathbf{0 . 7 3 4}} \\
0.559 \\
0.962 \\
\text { ] }\end{array}$ \\
\hline \multicolumn{2}{|l|}{ STATS TEST } & & $\left(\chi^{2}{ }_{1}=0.13, \mathrm{P}=0.72\right)$ & & $\left(\chi_{1}^{2}=5.18, \mathrm{P}=0.023\right)$ & \\
\hline \multicolumn{7}{|l|}{ Domesticated animals } \\
\hline No & 1240 & 49.9 & $6.3[4.97-7.85]$ & 1 & 11.7 [9.90-13.48] & 1 \\
\hline Yes & 1246 & 50.1 & $7.8[6.31-9.50]$ & $\begin{array}{c}1.258[ \\
0.924- \\
1.713 \\
]\end{array}$ & $11.6[9.86-13.42]$ & $\begin{array}{c}\frac{0.995}{[} \\
0.779 \\
1.271 \\
]\end{array}$ \\
\hline \multicolumn{2}{|l|}{ STATS TEST } & & $\left(\chi^{2}{ }_{1}=2.13, \mathrm{P}=0.15\right)$ & & $\left(\chi^{2}{ }_{1}=0.002, P=0.97\right)$ & \\
\hline \multicolumn{7}{|c|}{ No of species of animals } \\
\hline 0 & 1251 & 50.3 & $6.2[4.93-7.78]$ & 1 & 11.7 [9.89-13.45] & 1 \\
\hline 1 & 690 & 27.8 & 7.5 [5.81-9.67] & $\begin{array}{c}1.226[ \\
0.852- \\
1.764 \\
\text { ] }\end{array}$ & $12.2[9.98-14.74]$ & $\begin{array}{c}1.049 \\
0.788 \\
1.396 \\
]\end{array}$ \\
\hline 2 & 308 & 12.4 & $7.8[5.37-11.20]$ & $\begin{array}{c}1.271[ \\
0.790- \\
2.045 \\
]\end{array}$ & $13.0[9.79-17.04]$ & $\begin{array}{c}1.130 \\
0.776 \\
1.643 \\
]\end{array}$ \\
\hline 3 & 123 & 4.9 & $9.8[5.99-15.26]$ & $\begin{array}{c}1.626[ \\
0.859- \\
3.078 \\
]\end{array}$ & 6.5 [3.60-11.34] & $\begin{array}{c}\underline{\mathbf{0 . 5 2 7}} \\
0.252 \\
1.100 \\
]\end{array}$ \\
\hline 4 & 51 & 2.1 & 13.7 [8.04-22.07] & $\begin{array}{c}\underline{2.392}[ \\
0.043- \\
5.486 \\
]\end{array}$ & 13.7 [8.04-22.07] & $\begin{array}{c}0.473[ \\
0.145 \\
1.538 \\
]\end{array}$ \\
\hline 5 & 62 & 2.5 & $3.2[0.84-9.61]$ & $\begin{array}{c}0.500[ \\
0.120- \\
2.089 \\
]\end{array}$ & 14.5 [8.23-23.97] & $\begin{array}{c}1.285[ \\
0.618 \\
2.650 \\
]\end{array}$ \\
\hline 6 & 1 & 0.1 & $0.0[0.00-95.0]$ & - & $0.0[0.00-95.0]$ & - \\
\hline STATS TEST & & & $\left(\chi^{2}{ }_{6}=7.67, \mathrm{P}=0.26\right)$ & & $\left(\chi_{6}^{2}=7.08, P=0.31\right)$ & \\
\hline
\end{tabular}

The stats outputs that are significant are emphasized in bold, as is also the highest prevalence within the factor level

Table 4. The prevalence of combined helminths infections in subjects of different age, in relation to their mother's educational level 


\begin{tabular}{|c|c|c|c|c|c|c|c|c|c|c|c|c|}
\hline & $\begin{array}{c}\text { Age class } \\
1\end{array}$ & & & $\begin{array}{c}\text { Age class } \\
2 \\
\end{array}$ & & & $\begin{array}{c}\text { Age class } \\
3 \\
\end{array}$ & & & $\begin{array}{c}\text { Age class } \\
4 \\
\end{array}$ & & \\
\hline $\begin{array}{l}\text { Mother's } \\
\text { Education }\end{array}$ & $N$ & $\%$ & $95 \% \mathrm{CL}$ & $N$ & $\%$ & $95 \% \mathrm{CL}$ & $N$ & $\%$ & $95 \% \mathrm{CL}$ & $N$ & $\%$ & $95 \% \mathrm{CL}$ \\
\hline None & 215 & 10.2 & $\begin{array}{l}7.72- \\
13.33 \\
\end{array}$ & 547 & 9.7 & $\begin{array}{c}7.90- \\
11.78 \\
\end{array}$ & 557 & 4.8 & $\begin{array}{l}3.61- \\
6.44 \\
\end{array}$ & 384 & 3.9 & $\begin{array}{l}2.09- \\
6.94\end{array}$ \\
\hline $\begin{array}{l}\text { Elementary } \\
\text { School }\end{array}$ & 47 & 14.9 & $\begin{array}{l}5.89- \\
31.45\end{array}$ & 163 & 9.2 & $\begin{array}{l}5.15- \\
15.67\end{array}$ & 154 & 7.1 & $\begin{array}{l}3.80- \\
12.94\end{array}$ & 76 & 11.8 & $\begin{array}{l}5.96- \\
21.78\end{array}$ \\
\hline $\begin{array}{l}\text { Intermediate } \\
\text { School }\end{array}$ & 7 & 0 & $\begin{array}{c}0.00- \\
37.71 \\
\end{array}$ & 36 & 5.6 & $\begin{array}{l}1.27- \\
17.26 \\
\end{array}$ & 28 & 0 & $\begin{array}{c}0.00- \\
11.94\end{array}$ & 10 & 10.0 & $\begin{array}{l}0.52- \\
44.64\end{array}$ \\
\hline High School & 25 & 0 & $\begin{array}{c}0.00- \\
13.36 \\
\end{array}$ & 75 & 1.3 & $0.12-7.79$ & 71 & 5.6 & $\begin{array}{l}2.02- \\
13.74 \\
\end{array}$ & 30 & 6.7 & $\begin{array}{l}1.20- \\
21.34 \\
\end{array}$ \\
\hline Tertiary level & 9 & 22.2 & $\begin{array}{l}4.11- \\
55.82\end{array}$ & 35 & 2.9 & $\begin{array}{l}0.32- \\
13.16\end{array}$ & 13 & 15.4 & $\begin{array}{l}2.81- \\
43.39\end{array}$ & 4 & 25.0 & $\begin{array}{l}1.28- \\
75.13\end{array}$ \\
\hline
\end{tabular}

\section{Figures}

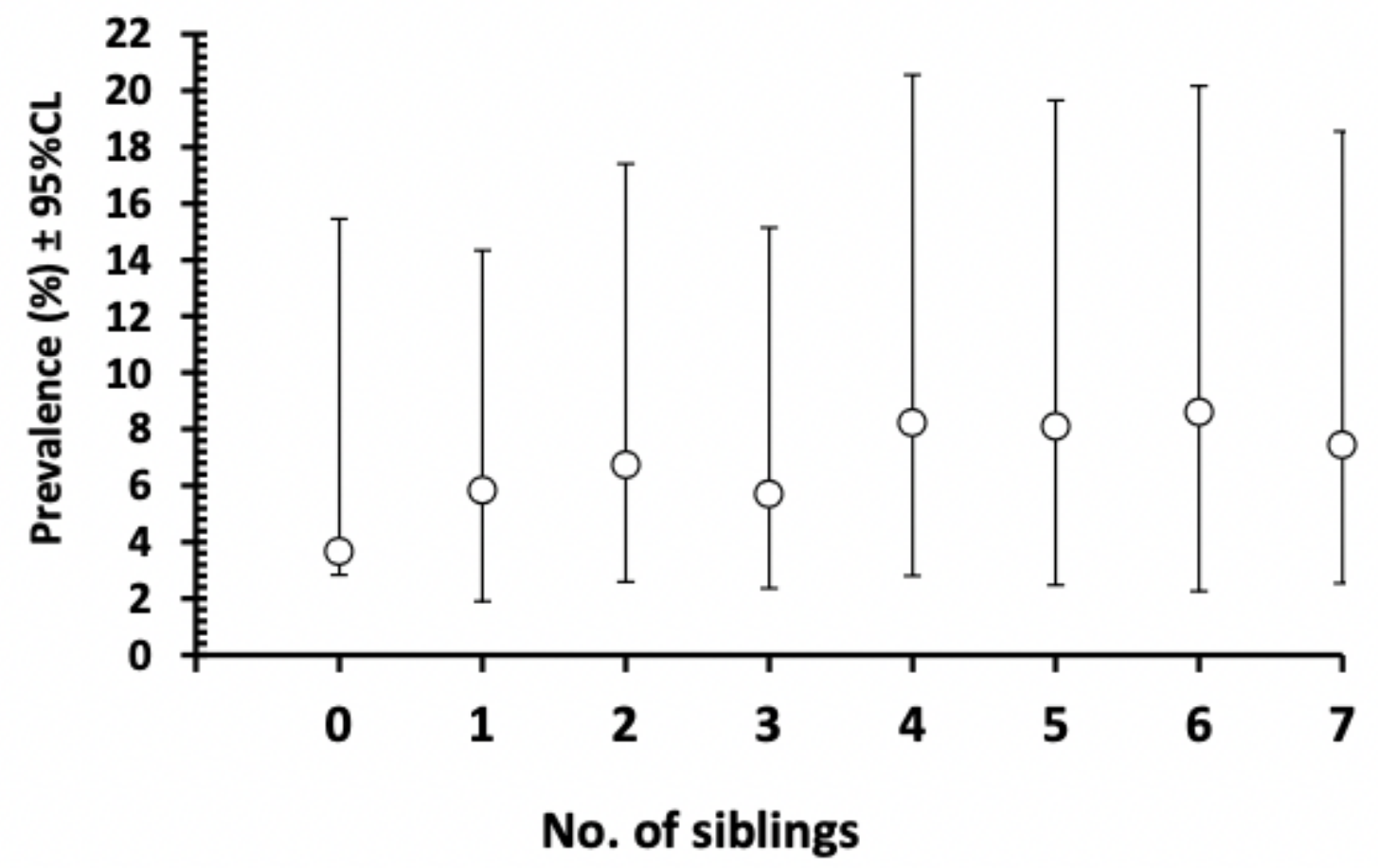

Figure 1

Relationship between the prevalence of combined helminths and number of siblings in the family of each subject. The value of 7 siblings actually represents a range from 7 to 16 . Despite the wide overlapping $95 \% \mathrm{CL}$, the correlation based on the mean value which is significant and positive ( $R s=0.76, n=8$, $\mathrm{P}=0.028)$ 